\title{
Effects of Potentilla fulgens on the Changes Made in the Retinal Damage Induced by Traumatic Head Injury
}

\author{
Efectos de Potentilla Fulgens en los Cambios Producidos Debido \\ al daño Retinal Inducido por Lesión Traumática en la Cabeza
}

\author{
Özevren Hüseyin ${ }^{1}$ \& Deveci Engin ${ }^{2}$
}

ÖZEVREN, H. \& DEVECI, E. Effects of Potentilla fulgens on the changes made in the retinal damage induced by traumatic head injury. Int. J. Morphol., 35(3):840-844, 2017.

SUMMARY: Traumatic head injury is a leading cause of mortality and morbidity. As a result of head trauma occurring in the retina of the various biochemical, histological and immunohistochemical effects were investigated. Sprague-Dawley rats were subjected to traumatic brain injury with a weight-drop device using $300 \mathrm{~g}-1 \mathrm{~m}$ weight-height impact. Twenty one rats were divided into three groups, as group 1 (vehicle-treated control), group 2 (vehicle-treated trauma) group 3 trauma + Potentilla fulgens ( P. Fulgens) $400 \mathrm{mg} /$ $\mathrm{kg} /$ day, i.p.). Distilled water was used as vehicle. All rats were decapitated 5 days after the induction of trauma, and the protective effects of $P$. Fulgens were evaluated by histological, immunohistochemical and biochemical analyses. Although further studies are necessary to evaluate the time-and dose-dependent neuroprotective effects of $P$. Fulgens. Depending on whether trauma inhibits apoptosis of photoreceptor cells, ganglion cells, it is thought that the the support against the degeneration of neural connections can be considered. This study indicates that P.Fulgens is potentially useful for the treatment of eye disorders induced by traumatic brain injury.

KEY WORDS: Traumatic injury; Retina; Potentilla fulgens; Rat.

\section{INTRODUCTION}

Traumatic brain injury (TBI) leads to a substantial number of deaths and cases of permanent disability. Many studies related to traumatic brain injury have been performed. This traumatic damage is caused by damage to the retinal ganglion cell, outer nuclear layer, and neuroglia, and the effects on the eye and visual system are diminished (Mohan et al., 2013; Zou et al., 2013; Wang et al., 2014). The authors found a decrease in retinal nerve fiber layer (RNFL) thickness and a decrease in pattern electroretinography (ERG) 3 to 4 months after injury, which correlated with punctate regions of reduced cellularity in the ganglionic layer and damage to the optic nerve (Mohan et al.) Potentilla fulgens is an alpine plant of Western Himalayas which is consumed in all parts of the world for its promising medicinal properties. Pharmacologically, the aerial and root portions of the plant are reported to have antioxidant (in vitro models), antitumor, hypoglycemic and antihyperglycemic activities (Syiem et al., 2003; Syiem et al., 2009; Jaitak et al., 2010). The general signs and symptoms of toxicity, food and water intake and mortality rates of animals were observed within $72 \mathrm{~h}$ post-treatment. From these observations, lethal dose $50 \%$ (LD50) was calculated using
SPSS software (Chen et al., 2009). GFAP is a 50-52 kDa acidic cytoskeletal protein. It is a marker protein of colloid cell, with plenty and exclusive expression in it. GFAP can be used to mark the post trauma changes of colloid cell, and normally GFAP is under the dynamic adjustment of glia cells (Zhang et al., 2004). Post trauma proliferated GFAP-positive colloid cell can promote caryocinesia of colloid cell, causing the differentiation of primitive progenitor cell towards mature glia cell. Various kinds of central nervous system lesions can induce colloid cell response (Austin et al., 1995). Cadherins are a family of transmembrane glycoproteins that mediate calciumdependent cell-to-cell adhesion in solid tissues. Numerous isoforms of cadherin have been identified in a tissue-specific manner and shown to regulate morphogenesis through homophilic binding (Nose et al., 1988; Takeichi et al., 1990). E-cadherin is responsible for stable cell-to-cell adhesion. The alteration in the E-cadherin molecule in the retinal cellular junction can play a role in visual function by affecting the cell-cell complex. Potentilla fulgens effects on changes in the retina after head trauma in the study were investigated by biochemical, histological and immunohistochemical methods.

\footnotetext{
${ }^{1}$ Departments of Neurosurgery, Dicle University School of Medicine, Diyarbakir, Turkey

${ }^{2}$ Department of Histology and Embryology, Dicle University School of Medicine, Diyarbakir, Turkey
} 


\section{MATERIAL AND METHOD}

The investigation was conducted in accordance with the Guide for the Care and Use of Laboratory Animals published by US National Institutes of Health (NIH Publication no. 85-23, revised 1996). All experimental protocols were approved by the Dicle University Animal Care and Use Committee. Male Sprague-Dawley rats (300-350 g) were housed in an air-conditioned room with 12-h light and dark cycles, where the temperature $\left(23 \pm 2{ }^{\circ} \mathrm{C}\right)$ and relative humidity (65-70\%) were kept constant. The animals were anesthetized by an intraperitoneal injection of $5 \mathrm{mg} / \mathrm{kg}$ xylazine $\mathrm{HCl}$ (Rompun, Bayer HealthCare AG, Germany) and $40 \mathrm{mg} / \mathrm{kg}$ ketamine $\mathrm{HCl}$ (Ketalar, Pfizer Inc., USA), and were allowed to breathe spontaneously. A rectal probe was inserted, and the animals were positioned on a heating pad that maintained the body temperature at $37{ }^{\circ} \mathrm{C}$. Briefly, a trauma device which works by dropping a constant weight from a specific height through a tube was used. Thirty minutes after the trauma, rats were injected either saline or Potentilla fulgens $(400 \mathrm{mg} / \mathrm{kg} /$ day) via intraperitoneally. On the fifth day all the 40 animals were killed after TBI. Each group consisted of 10 animals. These rats were used for biochemical and histopathological analysis. The MDA level and SOD, GSH-Px, and CAT activity were determined in each retina and the average values of each group were calculated

Statistical analysis. Statistical analysis was carried out using GraphPad Prism 4.0 software (GraphPad Software, 2003, San Diego, CA, USA). All data are presented as mean \pm standard deviation (SD). Groups of data were compared with an analysis of variance (ANOVA) followed by Tukey's multiple comparison tests. Values of $\mathrm{p}<0.05$ were considered as significant.

\section{RESULTS AND DISCUSSION}

When the trauma group was compared with the control and P. Fulgens groups, the MDA values were significantly increased $(\mathrm{p}<0.05)$. Treatment with $P$. Fulgens significantly decreased the MDA levels compared with the trauma group $(\mathrm{p}<0.05)$. There were no statistically significant differences between the control and P. Fulgens groups $(\mathrm{p}=0.488)$.Following TBI, tissue GSH-Px levels decreased significantly when both the control and P. Fulgens

Table I. Biochemical results relevant to the study groups.

\begin{tabular}{llclr}
\hline Groups & Control group & Potentilla. Fulgens group & Trauma & Trauma + Pot \\
MDA (nmo $/ \mathrm{g})$ & $20.71 \pm 1.19$ & $20.31 \pm 0.59$ & $34.88 \pm 0.99^{*}$ & 27.71 \\
\hline GSH-Px (U/g) & $24.17 \pm 0.43$ & $24.44 \pm 0.58$ & $15.69 \pm 0.63^{*}$ & 21.21 \\
SOD (U/g) & $0.89 \pm 0.028$ & $0.90 \pm 0.022$ & $0.58 \pm 0.018^{*}$ & $0.78 \pm$ \\
CAT (K/g) & $1.60 \pm 0.003$ & $1.59 \pm 0.006^{*}$ & $1.26 \pm 0.049^{*}$ & $1.45 \pm$ \\
\hline
\end{tabular}

Values are represented as mean \pm SD. MDA: malondialdehyde, GSH-Px: glutathione peroxidase, SOD: superoxide dismutase, CAT: Catalase $* \mathrm{p}<0.05$, versus control, $+\mathrm{p}<0.05$, trauma $+P$. Fulgens versus trauma
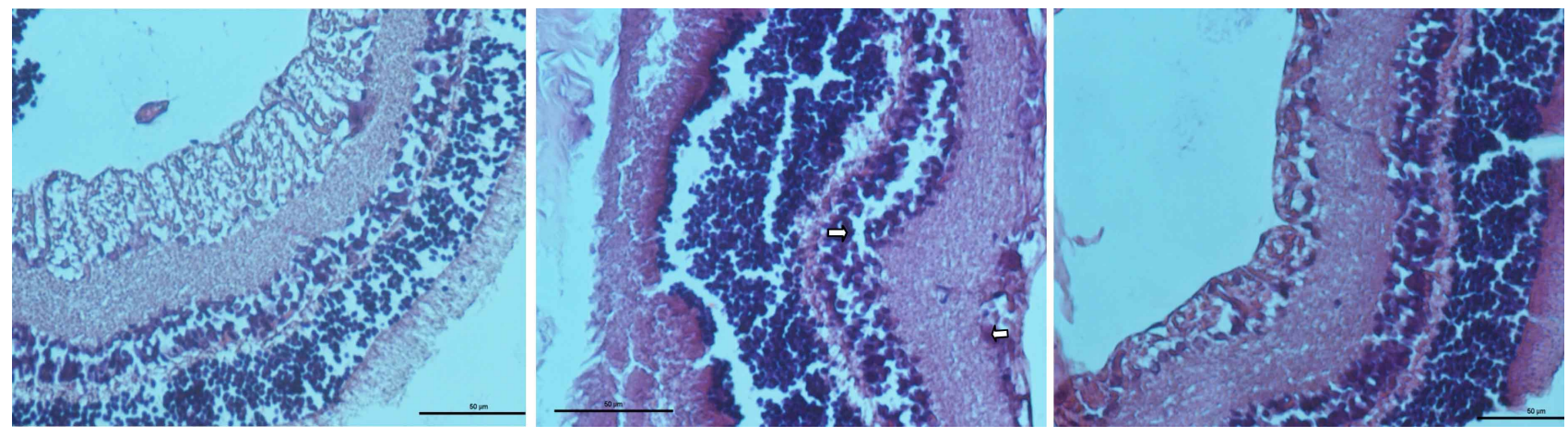

Fig. 1A .Control group: Normal appearance of the internal and outer nuclear layers and the normal organization of the retinal ganglionic layer. H-E staining Bar $50 \mu \mathrm{m}$, B-Trauma group, Organization and degeneration of cells in the inner and outer nuclear layers (arrow), dilation and hemorrhage in the blood vessels of the ganglionic layer (arrow), H-E staining Bar $50 \mu \mathrm{m}$. C. Trauma+P.fulgens group: Degeneration of cells in the inner and outer nuclear layers, degeneration of the inner and outer plexiform layers, fibrous structures regular shedding of the ganglionic layer, no dilatation and no bleeding in the blood vessels of the ganglionic layer, H-E staining Bar $50 \mu \mathrm{m}$, 

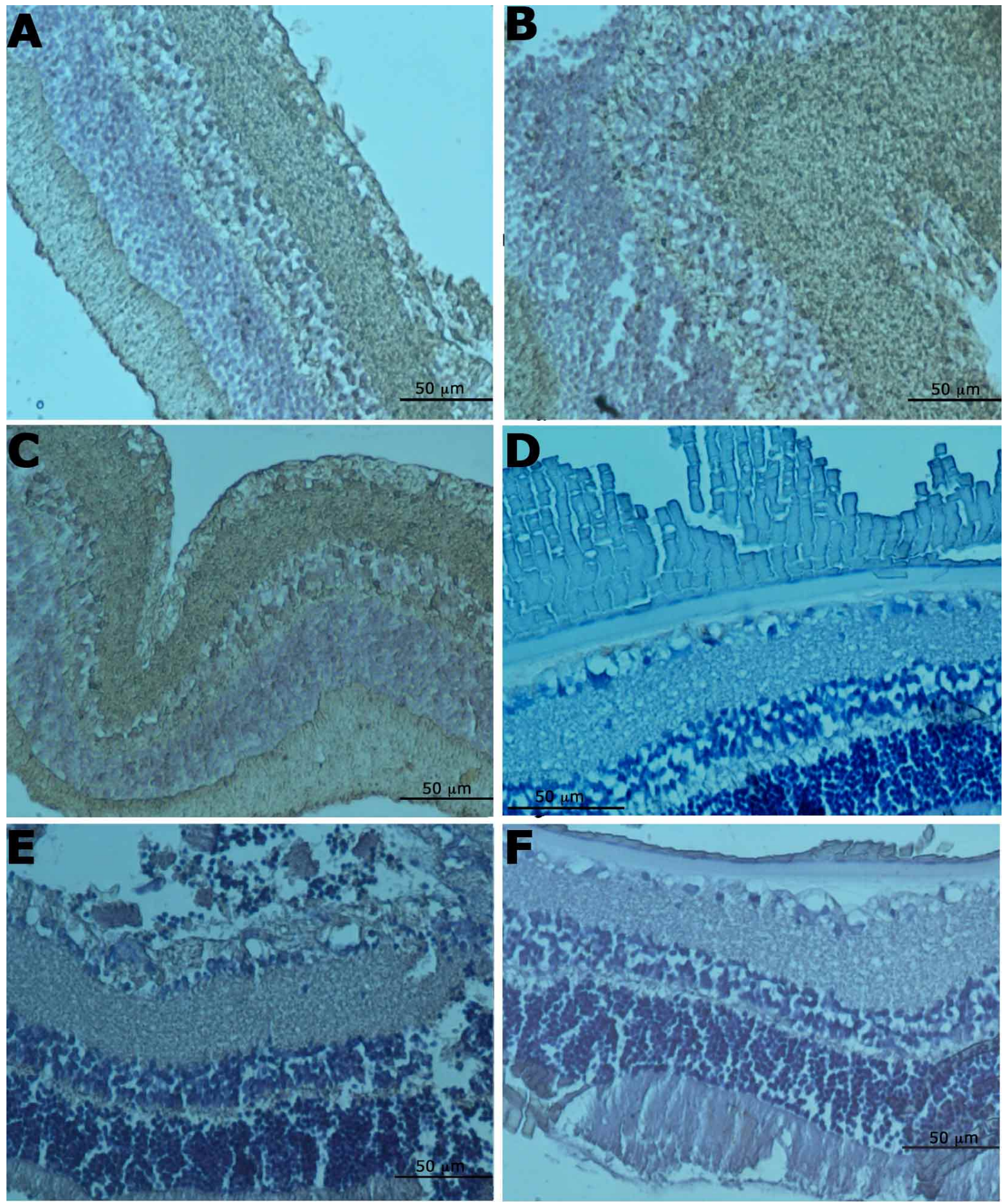

Fig. 2A. Control group: Regular distribution of E-cadherin expression in the ganglionic layer, regular internal and external plexiform layers in cells in the inner and outer nuclear layers, E-cadherin immunohistochemical staining Bar $50 \mu \mathrm{m}$. B. Trauma group: The separation in the cells in the inner and outer nuclear layers and the expression of E-cadherin is weak (arrow), E-cadherin immunohistochemical staining Bar $50 \mu \mathrm{m}$. C. Trauma+P.fulgens group: E-cadherin expression is positive in cells in the inner and outer nuclear layer, membranes and cellular connections, E-cadherin immunohistochemical staining Bar $50 \mu \mathrm{m}$, D. Control group: GFAP protein expression in the ganglionic layer and inner and outer layers plexiform GFAP immunohistochemical staining Bar $50 \mu \mathrm{m}$, E. Trauma group An increase in GFAP expression in the ganglionic layer,GFAP immunohistochemical staining Bar $50 \mu \mathrm{m}$. F. Trauma+P.fulgens group:Weak GFAP expression in plexiform layer and ganglion cells, GFAP immunohistochemical staining Bar $50 \mu \mathrm{m}$. 
groups were compared with the trauma group $(\mathrm{p}<0.05)$. Treatments with $P$. Fulgens significantly increased the tissue GSH-Px levels compared with the trauma group $(\mathrm{p}<0.05)$. There were no also significant differences between the control and $P$. Fulgens groups $(\mathrm{p}=0.383)$. When the tissue SOD activities of the control and $P$. Fulgens groups were compared with that of the trauma group, a statistically significant difference was observed $(\mathrm{p}<0.05)$; these data showed that after TBI, tissue SOD activity was decreased. Treatment with $P$. Fulgens significantly increased the tissue SOD activity $(\mathrm{p}<0.05)$. There were no significant differences between the control and P. Fulgens groups $(\mathrm{p}=0.496)$. Following TBI, tissue CAT activity decreased significantly when both the control and P. Fulgens groups were compared with the trauma group $(\mathrm{p}<0.05)$. Treatments with $P$. Fulgens significantly increased the tissue CAT activity compared with the trauma group $(\mathrm{p}<0.05)$.There were significant differences between the control and P. Fulgens groups ( $\mathrm{p}<$ 0.05 ). The biochemical results of the study are summarized in Table I.

Traumatic brain injury (TBI) is significantly associated with the over-production of reactive oxygen species. Traumatic brain injury self-reported visual complaints and symptoms such as blurry vision and photosensitivity and visual impairment such as visual acuity loss and visual field defects are reported (Brahm et al., 2009). Cadherins play distinctive roles in retinal regeneration. The differentiation between the signal paths of cells and has a fundamental role in the identification of cell-cell contact (Austin et al.; Dorsky et al., 1997). Tzekov et al. (2014) observed that cellularity decreased in the inner retina layer and ganglionic layer after trauma. In our study, it was observed that the inner and outer nuclear layer cellular integrity decreased after trauma, and the integrity of membranes deteriorated (Fig. 2b). GFAP is the major protein of glial intermediate filaments in astrocytes. It has been proposed as a specific marker for assessing astrocytic response to injury. An increase in GFAP expression is a cardinal feature of many pathological conditions of the CNS and astrocytes (Hausmann et al., 2000; Yu et al., 2004). GFAP is a $51-\mathrm{kDa}$ intermediate filament protein found in the astrocytes, neuroglia end-feet and processes. Although neuroglia in normal rat retinas express little or no GFAP (Bignami \& Dahl, 1979). Increased expression of GFAP in neuroglia in the retina and in astrocytes of the optic nerve is a well-known biomarker of retinal degeneration (Lewis \& Fisher, 2003). In our study, GFAP expression increased in retina after trauma (Fig. 2e). Increased GFAP expression in the retina may be the result of an inflammatory response and tissue damage after Traumatic head injury. It is thought that the integrity of the cell-cell junction can be protected and the antioxidant effect as a result of the regulation of the glial structure and the modification of the affected mullerian cells. We believe that $P$. Fulgens may be useful in preventing retinal damage resulting from traumatic head trauma, especially when used in clinics with adequate dosing and administration methods.

ÖZEVREN, H. \& DEVECI, E. Efectos de Potentilla fulgens en los cambios producidos debido al daño retinal inducido por lesión traumática en la cabeza. Int. J. Morphol., 35(3):840-844, 2017.

RESUMEN: El trauma de cráneo es una de las principales causas de morbilidad y mortalidad. Como resultado de un traumatismo craneal, la retina puede sufrir diversos efectos bioquímicos, histológicos e inmunohistoquímicos. Veintiún ratas SpragueDawley fueron sometidas a lesión craneal traumática con un dispositivo, de caída de peso, usando un impacto de 300 g-1 m de peso-altura. Las ratas fueron divididas en tres grupos: grupo 1 (control), grupo 2 (traumatismo) y grupo 3 trauma + Potentilla fulgens (400 mg / kg / día, i. p.). Se usó agua destilada como vehículo en todos los grupos. Las ratas fueron decapitadas 5 días después de la inducción del trauma, y se evaluaron los efectos protectores de $P$. Fulgens mediante análisis histológicos, inmunohistoquímicos y bioquímicos. Es necesario realizar más estudios para evaluar los efectos neuroprotectores, dependientes del tiempo y la dosis, de P. Fulgens. Dependiendo si el trauma inhibe la apoptosis de las células fotorreceptoras, se estima que la disposición de las células ganglionares ayuda contra la degeneración de las conexiones neuronales. P. Fulgens ha demostrado ser efectivo para el tratamiento de los trastornos oculares inducidos por lesión cerebral traumática.

PALABRAS CLAVE: Lesión traumática; Retina; Potentilla fulgens; Rata.

\section{REFERENCES}

Austin, C. P.; Feldman, D. E.; Ida, J. A. Jr. \& Cepko, C. L. Vertebrate retinal ganglion cells are selected from competent progenitors by the action of Notch. Development, 121(11):3637-50, 1995.

Bignami, A. \& Dahl, D. The radial glia of Müller in the rat retina and their response to injury. An immunofluorescence study with antibodies to the glial fibrillary acidic (GFA) protein. Exp. Eye Res., 28(1):63-9, 1979.

Brahm, K. D.; Wilgenburg, H. M.; Kirby, J.; Ingalla, S.; Chang, C. Y. \& Goodrich, G. L. Visual impairment and dysfunction in combat-injured servicemembers with traumatic brain injury. Optom. Vis. Sci., 86(7):81725, 2009.

Chen, W.; Fu, X. B.; Ge, S. L.; Sun, T. Z.; Li, W. J. \& Sheng, Z. Y. Acid fibroblast growth factor reduces rat intestinal mucosal damage caused by ischemia-reperfusion insult. World J. Gastroenterol., 11(41):647782, 2009.

Dorsky, R. I.; Chang, W. S.; Rapaport, D. H. \& Harris, W. A. Regulation of neuronal diversity in the Xenopus retina by Delta signalling. Nature, 385(6611):67-70, 1997.

Hausmann, R.; Riess, R.; Fieguth, A. \& Betz, P. Immunohistochemical investigations on the course of astroglial GFAP expression following human brain injury. Int. J. Legal Med., 113(2):70-5, 2000.

Jaitak, V.; Kaul, K. \& Kaul, V. K. Review on pharmaceutical properties 
and conservation mesures of $P$. Fulgens Wall. ex Hook- A medicinal endangered herb of higher Himalya. Indian J. Nat. Prod. Resour., 2:298$306,2010$.

Lewis, G. P. \& Fisher, S. K. Up-regulation of glial fibrillary acidic protein in response to retinal injury: its potential role in glial remodeling and a comparison to vimentin expression. Int. Rev. Cytol., 230:263-90, 2003.

Mohan, K.; Kecova, H.; Hernandez-Merino, E.; Kardon, R. H. \& Harper, M. M. Retinal ganglion cell damage in an experimental rodent model of blast-mediated traumaticbrain injury. Invest. Ophthalmol. Vis. Sci., 54(5):3440-50, 2013.

Nose, A.; Nagafuchi, A. \& Takeichi, M. Expressed recombinant cadherins mediate cell sorting in model systems. Cell, 54(7):993-1001, 1988.

Syiem, D.; Khup, P. Z. \& Syiem, A. B. Effects of Potentilla fulgens Linn. On carbohydrate and lipid profiles in diabetic mice. Pharmacol. Online, 2:787-95, 2009.

Syiem, D.; Syngkai, C.; Kharbuli, B.; Kayang, H. \& Khongwir, B. S. Antitumor activity of crude root extract of Potentilla fulgens. Indian Drugs, 40:124-5, 2003.

Takeichi, M. Cadherins: a molecular family important in selective cell-cell adhesion. Annu. Rev. Biochem., 59:237-52, 1990.

Tzekov, R.; Quezada, A.; Gautier, M.; Biggins, D.; Frances, C.; Mouzon, B.; Jamison, J.; Mullan, M. \& Crawford, F. Repetitive mild traumatic brain injury causes optic nerve and retinal damage in a mouse model. $J$. Neuropathol. Exp. Neurol., 73(4):345-61, 2014.

Wang, H. C.; Choi, J. H.; Greene, W. A.; Plamper, M. L.; Cortez, H. E.; Chavko, M.; Li, Y.; Dalle, Lucca, J. J. \& Johnson, A. J. Pathophysiology of blast-induced ocular trauma with apoptosis in the retina and optic nerve. Mil. Med., 179(8 Suppl.):34-40, 2014.

Yu, H. M.; Yuan, T. M.; Gu, W. Z. \& Li, J. P. Expression of glial fibrillary acidic protein in developing rat brain after intrauterine infection. Neuropathology, 24(2):136-43, 2004.

Zhang, Y.; Kardaszewska, A. K.; van Veen, T.; Rauch, U. \& Perez, M. T. Integration between abutting retinas: role of glial structures and associated molecules at the interface. Invest. Ophthalmol. Vis. Sci., 45(12):4440-9, 2004

Zou, Y. Y.; Kan, E. M.; Lu, J.; Ng, K. C.; Tan, M. H.; Yao, L. \& Ling, E. A. Primary blast injury-induced lesions in the retina of adult rats. $J$. Neuroinflammation, 10:79, 2013.

\author{
Corresponding author: \\ Dr. Engin Deveci \\ Department of Histology and Embryology \\ Dicle University Faculty of Medicine \\ Diyarbakır \\ TURKEY
}

Email: engindeveci64@gmail.com

Received: 15-12-2016

Accepted: 24-03-2017 